\title{
A FORM OF LIPOIDOSIS OF THE ADRENAL CORTEX IN AN INFANT
}

\author{
BY \\ A. T. SANDISON \\ From the Departments of Pathology, Royal Hospital for Sick Children, \\ Western Infirmary and University of Glasgow
}

(RECEIVED FOR PUBLICATION JUNE 22, 1955)

The lipoidoses, or diseases of lipoid metabolism, have been extensively studied in recent years. No case similar to that described below has been discovered in the literature, the essential feature being the restriction of the process to the adrenal cortices and to heterotopic adrenal cortex. The adrenals were enlarged, pale and obviously grossly abnormal, the cortex being replaced by xanthomatous cells.

The lesion, in its fully developed state at least, is not likely to be missed even on cursory examination. As no cases have been traced the condition is probably one of considerable rarity.

\section{Case Report}

The child, a female, was born at home, weighed $2.8 \mathrm{~kg}$., and failed to thrive despite repeated changes in the feeding régime. She was admitted at the age of 3 months to the Royal Hospital for Sick Children, Glasgow, five days before her death when she was noted to be obviously marasmic and to have a dusky pigmentation of the skin. A systolic murmur was heard at the heart base. Her condition continued to deteriorate despite intravenous fluid therapy. No hormone assays were made.

At necropsy (P.M.8831) the body weight was $3.4 \mathrm{~kg}$., the normal body weight for this age being at least $5 \mathrm{~kg}$. Pigmentation was not obvious in the light of the postmortem room. The heart showed a patent ductus arteriosus. The alimentary tract appeared normal and culture of the intestinal content for pathogenic organisms was negative. The only significant finding was that both adrenals were large, firm and pale (left adrenal $3 \mathrm{~g}$., $4 \times 2 \times 1 \mathrm{~cm}$.). At this age the normal combined weight of the adrenals is $2-3 \mathrm{~g}$. On section, the glands were putty-white, with no evidence of haemorrhage (Fig. 1). The remaining endocrine organs appeared normal.

Histological examination of the heart, trachea, thyroid, thymus, major bronchi, lungs, liver, spleen, pancreas, mesenteric lymph nodes, bowel, spinal cord, medulla oblongata, cerebral cortex, breasts, uterus, tubes and ovaries showed no significant abnormality.

The adrenals showed complete absence of the normal architecture except for occasional scattered islets of recognizable medullary tissue. The cortex showed no trace of the usual zonal arrangement (Fig. 2). The cortical cells resembled neither those of the adult nor of the foetus nor were they those of the hyperplastic adrenal cortex in the adreno-genital syndrome. They were much larger than normal and polyhedral in shape, with a smaller, darkly-stained eccentrically-placed nucleus which might be round or oval. The cytoplasm stained faintly eosinophilic with haemalum and eosin and was much more finely foamy than that of the normal cortical cells. The gland was irregularly trabeculated by thin fibrous strands which sometimes expanded into areas of vascular fibrous stroma. The cells closely resembled xanthoma cells. Throughout the cortex, small rather spindleshaped cholesterol crystal clefts were seen, with related multinucleated giant cells (Fig. 3). The islets of medullary tissue were scattered and compressed, but the cells appeared to be essentially normal. The vascular arrangements of medulla and cortex also appeared normal.

Paraffin sections stained by Mallory's method showed fine collagen fibrils surrounding the great majority of the cells of the cortex. There were scanty areas, usually adjacent to the cortical surface and sometimes wedgeshaped, in which the cells contained fine fuchsinophil granules. These appearances were paralleled in sections stained by Lieb's phosphotungstic-acid haematoxylin. The Prussian blue reaction showed no significant amount of haemosiderin in the adrenal cells, although it was present in scanty amounts in the stroma.

The periodic-acid-Schiff method gave negative results. According to Pearse (1953) this excludes the presence of polysaccharides, mucopolysaccharides, mucoproteins, glycoproteins, the glycolipids and the cerebrosides (e.g., cerasin) and a group of unsaturated lipoids and phospholipids, including lecithin, cephalin, phosphatidyl, serine and sphingomyelin. It is of some importance to be able to exclude these latter lipoid substances because of their association with the lipoid diseases. Pearse points out that in Gaucher's disease the lipoid-containing cells are stained by the periodic-acid-Schiff technique and this we have confirmed.

Frozen sections stained with Sudan IV and Sudan black showed that the cortex contained large quantities of sudanophil material uniformly distributed. This was 


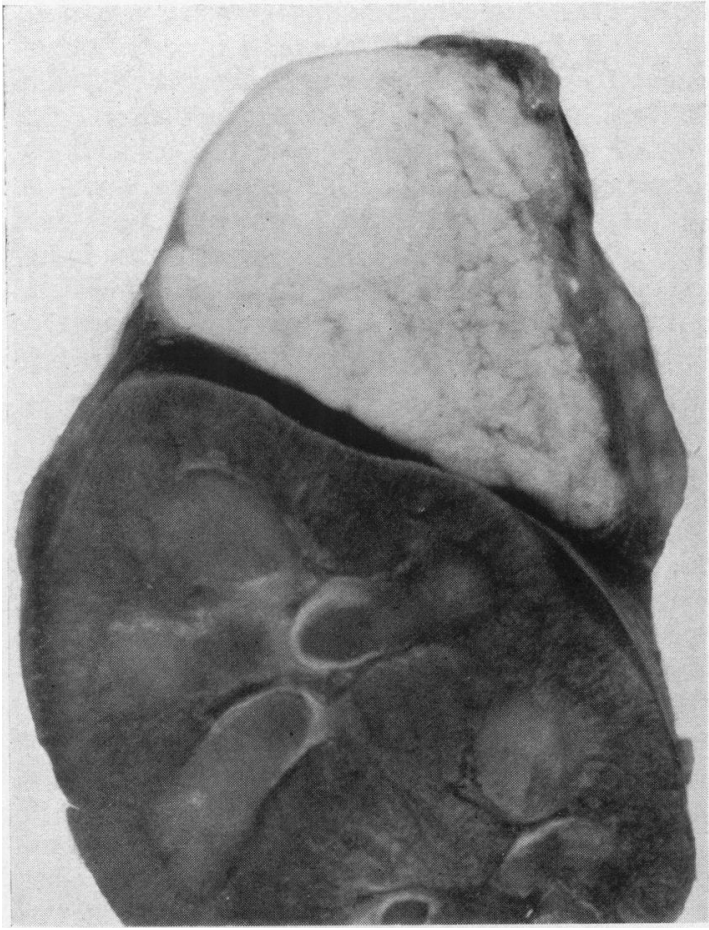

Fig. 1.-Macroscopic appearance of a kidney and adrenal to show loss of normal morphology of the latter. $\times 2 \cdot 5$

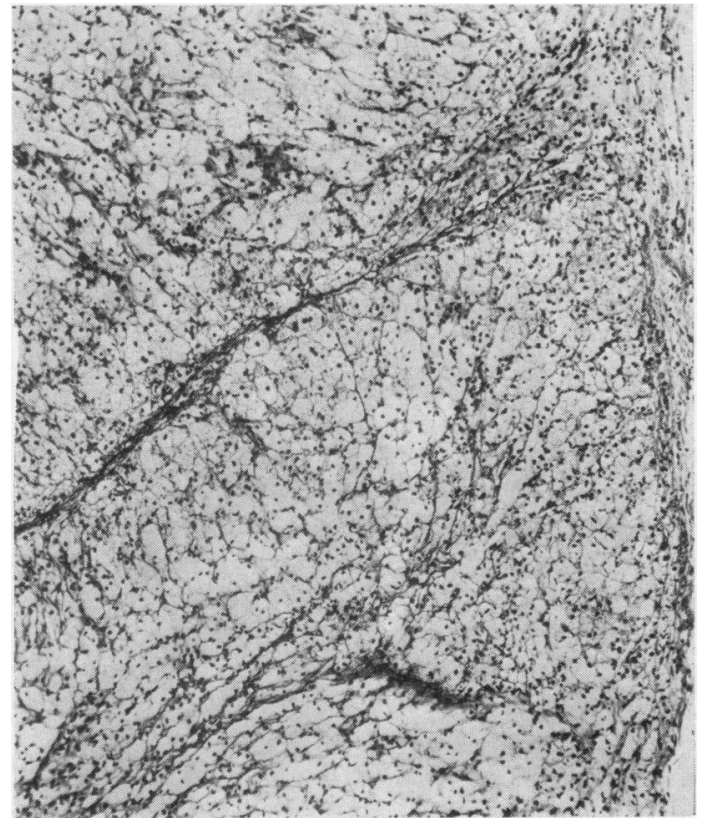

FIG. 2.-The adrenal cortex, showing loss of usual zonal arrangement and the atypical appearance of the cells of the cortex. Haemalum

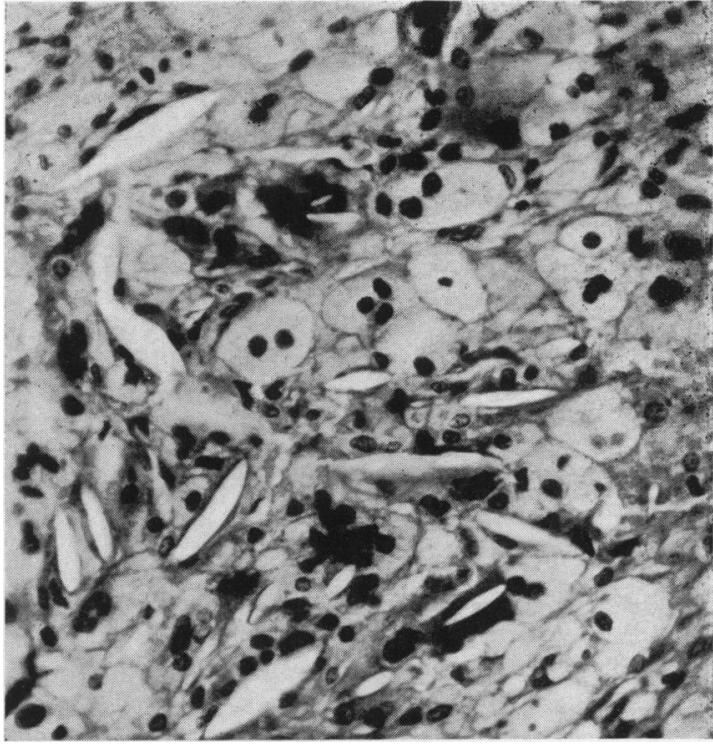

FIG. 3.-An aggregate of cholesterol crystal clefts with foreign-body giant cells. These are surrounded by cortical cells of atypical appearance. Haemalum and eosin $\times 280$.

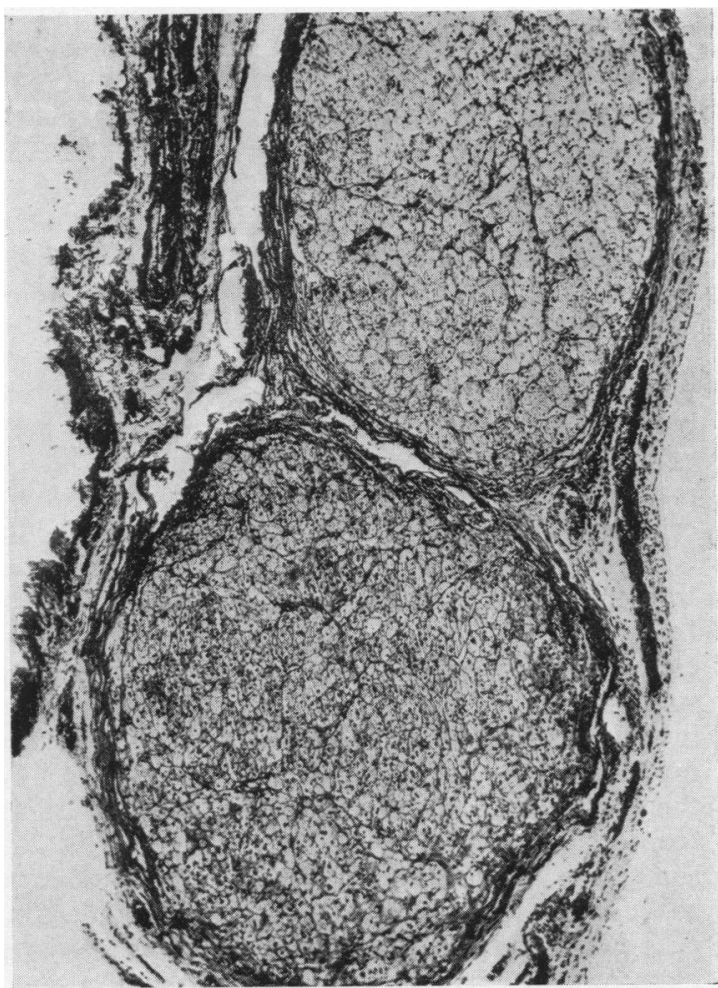

Fig. 4.-Heterotopic adrenal cortical tissue of similar nature associated with an ovary. Haemalum and eosin $\times 50$. 
mainly crystalline, although some droplets were also present. These crystals formed sheaves of slender acicular spicules which were highly refractile in reflected light and brightly anisotropic when examined with polarized light. The large clefts associated with the giant cell reaction did not show birefringence and were not sudanophil and presumably the contained cholesterol crystals must have been dislodged in preparation of the sections.

Two small nodules, $1 \mathrm{~mm}$. in diameter, of heterotopic adrenal cortex, presenting an appearance essentially similar to that of the adrenal cortex, were found close to one ovary, demonstrating that the affection was one of adrenal cortical tissue generally (Fig. 4).

The pituitary showed no gross abnormality. Celltype differentiation was incomplete.

\section{Discussion}

The adrenal glands in this case were obviously grossly abnormal both macroscopically and microscopically. No comparable case is to be found in the records of the Royal Hospital for Sick Children, Glasgow, nor, I am informed, has any such case been previously seen by MacDonald, Cappell or Baar. The condition is not described in the standard works on endocrinology of Grollman (1936), Young (1937), Soffer (1946 and 1951), Hartman and Brownell (1949), Williams (1950) or Yoffey (1952); on paediatrics of Nelson (1950); or on paediatric pathology of Potter (1952) or Morison (1952). No similar case is recorded in the bibliography of the physiology and pathology of the newborn for the period 1930-40 compiled by Antonov (1947) nor is there any relevant reference in the Cumulative Index Medicus until 1952.

Thannhauser (1950) chronicles no instance of generalized lipoidosis of the adrenal cortex. He points out, however, that the peri-adventitial cells of the adrenal act as reticulo-endothelial cells and may take up lipoid. Nests of lipoid-containing cells may be discovered in the adrenals in infantile Gaucher's disease and in Niemann-Pick's disease. In both, pigmentation of the skin has been observed. In neither of these diseases, however, is the adrenal ever solely affected. In Gaucher's disease, the spleen, liver, bone marrow and lymph nodes are involved, while in Niemann-Pick's disease the lipoid-containing cells are virtually ubiquitous. In this disease the adrenals may be enlarged and show foam cells localized between cortex and medulla, sometimes causing great thickening of the latter, as the foamy cells are here derived from the reticulum cells of the medulla. In these instances, melanin pigmentation of the skin may be the sole sign of endocrine disturbance. The lipoid-containing cells in Niemann-Pick's disease are isotropic, sudanophil, smaller than those of infantile Gaucher's disease, with rarely more than three nuclei in a cytoplasm which shows small droplets and stains bluish with Mallory's stain. In infantile Gaucher's disease the cells are larger, show many eccentric nuclei in a homogeneous, dense, wax-like cytoplasm which is not sudanophil and stains strongly blue with Mallory's stain. The cells in the present case in no way correspond with those of either condition. In the Hurler-Pfaundler syndrome of gargoylism the cells are not sudanophil and the adrenals are not affected.

Recently the syndrome of neonatal cortical insufficiency has been described by numerous authors, e.g., Butler, Ross and Talbot (1939), Thelander and Cholffin (1941) and Jaudon (1948). This is associated with an adrenogenital syndrome whose histological findings are described by Allibone, Baar and Cant (1947). The adrenal in this syndrome shows no similarity to the condition described above, and in the present case also there was no masculinization or pseudo-hermaphroditism. It seems, therefore, that no relationship exists between the adrenogenital syndrome and the present case.

Stoner, Whiteley and Emery (1953), in a comprehensive and well-illustrated paper on the effect of systemic disease on the adrenal cortex of the child, outline the post-natal development of the adrenals. They state that at birth there is little sudanophil material in the definitive cortex or in the so-called X-zone, and that the lipoid content increases with age.

Hartman and Brownell (1949) state that at birth the cholesterol content of the adrenal is only $15 \mathrm{mg}$. per g. Ether extracts, on the other hand, contain chiefly glycerol tristearate, and lecithin and cephalin have also been identified. They cite Rosenheim and Tebb to have demonstrated sphingomyelin and Coester cerebroside.

\section{Chemical Analysis}

Dr. R. P. Cook, of the Department of Biochemistry, Queen's College, Dundee, kindly made an analysis of a portion of the adrenal from this case and, in comparison, that from a 4-month-old male infant who died of fulminating respiratory infection.

The essential findings are as follows:

\begin{tabular}{|c|c|c|c|c|}
\hline & & & $\begin{array}{c}\text { Morbid Adrenal } \\
\text { (g.) }\end{array}$ & $\begin{array}{l}\text { Adrenal for } \\
\text { Comparison (g.) }\end{array}$ \\
\hline $\begin{array}{l}\text { Dry weight } \\
\text { Lipid extract } \\
\text { Total sterol } \\
\text { Free sterol } \\
\text { Ratio total to } \\
\text { Phospholipid }\end{array}$ & $\begin{array}{l}\ldots \\
\ldots \\
\cdots \\
\text { e sterol } \\
\ldots\end{array}$ & $\begin{array}{l}\cdots \\
\cdots \\
\cdots \\
\cdots\end{array}$ & $\begin{array}{l}0.49 \\
0.34(70 \%) \\
0.082(16.8 \%) \\
0.026(5.3 \%) \\
3.3 \\
0.021\end{array}$ & $\begin{array}{l}1 \cdot 01 \\
0.80(80 \%) \\
0.059(5.9 \%) \\
0.025(2.5 \%) \\
2.35 \\
0.014\end{array}$ \\
\hline
\end{tabular}


Data concerning the lipoid content of the adrenal in childhood and its partition chemically are not readily available. Nevertheless, the figures obtained above show a marked difference in sterol content. There is, of course, a diminution of adrenal lipoid in cases of infection and it is uncertain to what extent this occurs in fulminating disease. Despite the absence of an acceptable control, which would be provided only by a child dying instantaneously for accidental reasons, these figures are published in the hope that data may eventually be accumulated which will give the requisite control values.

\section{Summary}

A case of apparent lipoidosis of the adrenal cortex in an infant is described.

This change affected only the adrenal cortex and a portion of heterotopic adrenal cortex associated with one ovary.

The essential change appears to be an increase in cortical sterol with disorganization of the normal zonal architecture of the cortex.

The clinical condition was consistent with adrenal insufficiency.

My thanks are due to Dr. J. H. Hutchison for permission to publish this case, to Messrs. L. Nicolson and
W. Mason for technical assistance and to Dr. R. P. Cook and Miss S. K. Bisset for the chemical analyses.

Professor D. F. Cappell and Drs. A. M. MacDonald and H. S. Baar examined the sections and I am grateful to them for advice and encouragement. I am also indebted to Professor M. J. Stewart for much helpful criticism.

\section{REFERENCES}

Allibone, E. C., Baar, H. S. and Cant, W. H. P. (1947). Archives of Disease in Childhood, $22,210$.

Antonov, A. N. (1947). 'Physiology and Pathology of the Newborn: Bibliography of Material for the Period 1930-40.' Monogr. ioliograph

Butler, A. M., Ross, R. A. and Talbot, N. B. (1939). J. Pediat., 15, 831 .

Grollman, A. (1936). The Adrenals. Baltimore.

Hartman, F. A. and Brownell, K. A. (1949). The Adrenal Gland. Philadelphia.

Jaudon, J. C. (1948). J. Pediat., 32, 641.

Morison, J. E. (1952). Foetal and Neonatal Pathology. London.

Nelson, W. E. (1950). Mitchell-Nelson Textbook of Pediatrics, Sth ed. Philadelphia and London.

Pearse, A. G. E. (1953). Histochemistry. Theoretical and Applied, p. 136. London.

Potter, E. L. (1952). Pathology of the Fetus and the Newborn. Chicago.

Soffer, L. J. (1946). Diseases of the Adrenals. Philadelphia.

- (1951). Diseases of the Endocrine Glands. Philadelphia.

Stoner, H. B., Whiteley, H. J. and Emery, J. L. (1953). J. Path. Bact., 66, 171

Thannhauser, S. J. (1950). Lipidoses. Diseases of the Cellular Lipid Metabolism, 2nd ed. New York.

Thelander, H. E. and Cholffin, M. (1941). J. Pediat., 18, 779

Williams, R. H. (1950). Textbook of Endocrinology. Philadelphia and London.

Yoffey, J. M. (1952). The Suprarenal Cortex. (5th Symposium Colston Research Society.) London.

Young, H. H. (1937). Genital Abnormalities, Hermaphroditism and Related Adrenal Diseases. Baltimore. 